\title{
Carbohydrate Changes in Sprouting Sweetpotato Roots
}

\section{W.W. Collins', W.M. Walter, Jr. ${ }^{2}$, and S. Torgersen-Belding ${ }^{3}$ North Carolina State University, Raleigh, NC 2769.5}

Additional index words. total sugars, dry matter, glucose, fructose, sucrose, alphaamylase

Sprout production in sweetpotato roots has been positively correlated with high dry matter (Jones, 1977) but is influenced by many environmental factors before and after bedding. These factors make it difficult to accurately measure or predict sprouting potential of large numbers of clones in a breeding program or in germplasm evaluation. Our objective was to evaluate levels of carbohydrate components during the presprouting and sprouting process as possible indicators of sprouting potential of sweepotato roots.

Storage roots of 'Carolina Nugget' and 'Travis' were presprouted at 30C and 90\% $\mathrm{RH}$ for 20 days and then placed in field beds for 25 days. Roots were sampled from three replications through presprouting and bedding at 2-, 3-, or 4-day intervals. Determinations of carbohydrates were made on freezedried material using published procedures (Johnson et al., 1964; Pharr and Sox, 1984; Walter et al., 1975).

'Carolina Nugget' produced significantly

Received for publication 5 Aug. 1988. Paper no. 10720 of the Journal Series of the North Carolina Agricultural Research Service, Raleigh, NC 276957643. Mention of a trademark or proprietary product does not constitute a guarantee or warranty of the product by North Carolina State Univ., nor does it imply approval to the exclusion of other products that may be suitable. The 'cost of publishing this paper was defrayed in part by the payment of page charges. Under postal regulations, this paper therefore must be hereby marked advertisement solely to indicate this fact.

'Professor, Dept. of Horticultural Science.

${ }^{2}$ Professor, USDA, ARS-SR and Dept. of Food Science.

${ }^{3}$ Research Technician, Dept. of Horticultural Science. more sprouts than 'Travis' during the 45 days of this study (Fig. 1). Number of sprouts increased slowly through presprouting for 'Carolina Nugget' and more rapidly once roots were bedded, and their number was just beginning to increase in 'Travis' after 45 days.

At the beginning of this experiment, significant differences existed between cultivars in each of the carbohydrate factors measured. 'Carolina Nugget' contained fewer reducing sugars (glucose and fructose) and total sugars than 'Travis' (data not shown) but was much higher in sucrose and dry-matter content (Fig. 1) and also in starch (data not shown). After 45 days, fructose and glucose had decreased by $81 \%$ and $43 \%$, respectively, in 'Travis', with no accompanying increase in sucrose levels. In contrast, glucose and fructose in 'Carolina Nugget' decreased steadily with an accompanying increase in sucrose, which reached a peak on day 27 (Fig. 1). This increase corresponds roughly with the date sprouting began to increase significantly in 'Carolina Nugget' and may indicate that a threshold level of sucrose was reached.

In this study superior sprouting was associated with a high initial carbohydrate content, as in previous studies, combined with a higher rate of disappearance of starch and reducing sugar during sprouting. In addition, a threshold level of sucrose may be necessary for rapid sprouting.

\section{Literature Cited}

Johnson, G., C. Lambert, D.K. Johnson, and S-G. Sunderwirth. 1964. Calorimetric determination of glucose, fructose and sucrose in plant material using a combination of enzymatic and chemical methods. J. Agr. Food Chem. 12:216219.
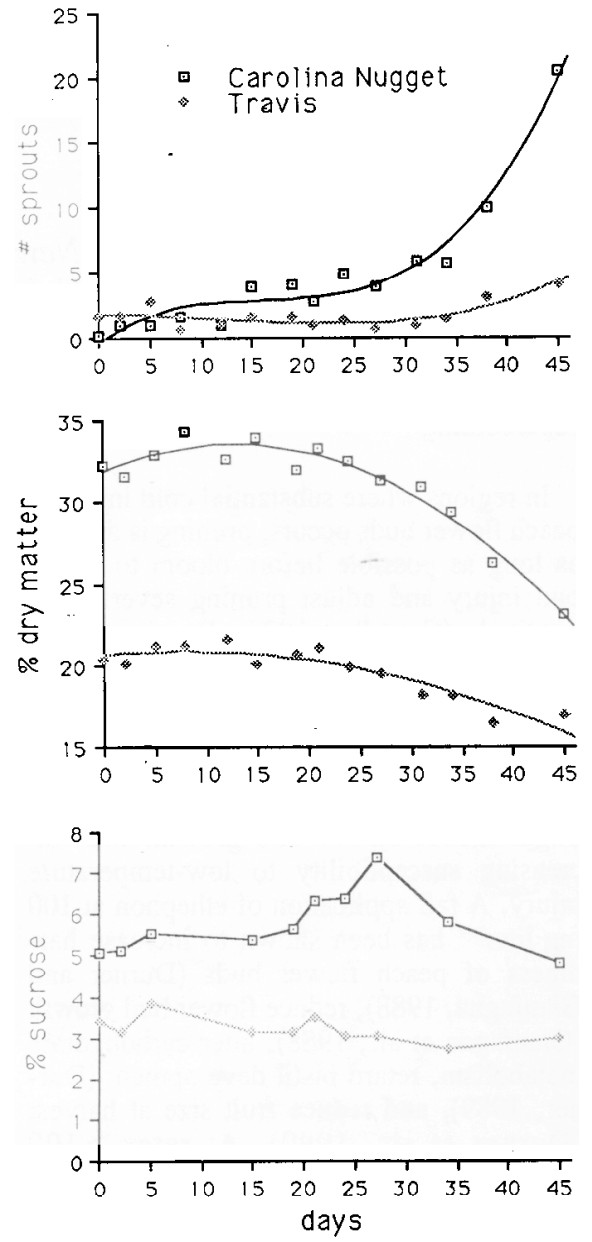

Fig. 1. Number of sprouts, percent dry matter, and percent sucrose in 'Carolina Nugget' and 'Travis' sweetpotato roots during 19 days of presprouting and 26 days of bedding.

Jones, A. 1977. Heritabilities of seven sweet potato root traits. J. Amer. Soc. Hort. Sci. 102:440442.

Pharr, D.M. and H.N. Sox. 1984. Changes in carbohydrates and enzyme levels during the sink to source transition of leaves of Cucumis sativus L., a stachyose translocator. Plant Sci. Lett. 35:187-193

Walter, W. M., Jr., A.E. Purcell, and A.M. Nelson. 1975. Effects of amylolytic enzymes on moistness and carbohydrate changes of baked sweet potato cultivars. J. Food Sci. 40:793796. 